\title{
Editorial
}

Dermatology

Published online: November 15, 2010

DOI: $10.1159 / 000321331$

\section{The Rhodoid Nevus: A Proposed Term for a So Far Unnamed Capillary Malformation}

\author{
Rudolf Happle \\ Department of Dermatology, University Medical Center, Freiburg, Germany
}

\section{Key Words}

Rhodoid nevus · Capillary malformation · Capillary

malformation-arteriovenous malformation $\cdot$ RASA 1

mutations $\cdot$ Nevus flammeus

\section{Introduction}

In 2003, a distinct autosomal dominant trait characterized by multiple, rather small capillary malformations of round or oval shape was described by Miikka Vikkula's team from Brussels [1]. They found that this phenotype that had previously been mapped to chromosome $5 \mathrm{q}[2$, $3]$, was caused by RASA1 mutations. Because the skin lesions were sometimes associated with a fast-flow arteriovenous malformation of the Parkes Weber type, they chose the name 'capillary malformation-arteriovenous malformation (CM-AVM)' [1]. In the meantime this peculiar vascular disorder has become a well-established entity with its own OMIM entry [4].

For clinical dermatologists, however, there still remains a major problem. How can we recognize the rather typical vascular lesions of this phenotype if they have no specific name? So far, all experts are describing the cutaneous hallmark of this autosomal dominant trait as 'cap- illary malformation' [1-7]. This term is incredibly broad and includes many vascular disorders such as nevus flammeus, nevus anemicus, angiokeratoma circumscriptum as well as nuchal or glabellar salmon patches [8]. As a consequence, the cutaneous lesions of CM-AVM have erroneously been called 'nevi flammei' [4] or 'port-wine stains' $[1-4,6]$.

For obvious reasons, the capillary malformation associated with CM-AVM syndrome should be identifiable by a separate name. Because the lesion is typically of a 'pink to red' color $[1,5,7]$, I propose the designation 'rhodoid

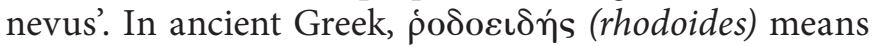
'rose-like' or 'rose-colored'. Accordingly, CM-AVM could also be called 'rhodoid nevus syndrome'.

The distinguishing criteria of rhodoid nevus (fig. 1) are summarized in table 1. Its color is lighter than that of nevus flammeus (fig. 2). On the other hand, its hue is usually darker than that observed in nevus roseus (fig. 3), a congenital skin lesion that is sometimes found to be associated with a macular nevus spilus, resulting in phacomatosis spilorosea [9-11]. Rhodoid nevi tend to be rather small and of round or oval shape [6, 7], and they show a haphazard distribution [5, 7]. By contrast, both nevus flammeus and nevus roseus are archetypically arranged in a checkerboard pattern [9]. As another distinguishing feature, the rhodoid nevus is often surrounded by a nar-

\section{KARGER}

Fax +41613061234

E-Mail karger@karger.ch

www.karger.com
C) 2010 S. Karger AG, Basel

$1018-8665 / 10 / 2214-0317 \$ 26.00 / 0$

Accessible online at: www.karger.com/drm
Rudolf Happle, MD

Department of Dermatology, University Medical Center Freiburg

Hauptstrasse 7, DE-79104 Freiburg (Germany)

Tel. +497612706 961, Fax +497612706 829

E-Mail rudolf.happle@uniklinik-freiburg.de 


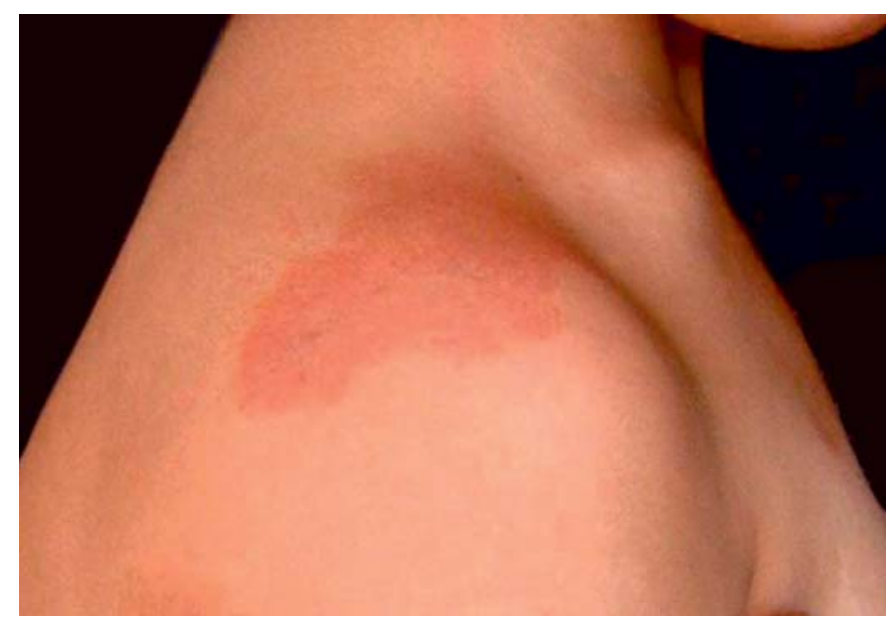

Fig. 1. Rhodoid nevus in a 12 -year-old girl with CM-AVM. A RASA1 mutation was found in this patient by Dr. M. Vikkula (Brussels, Belgium). Courtesy of Dr. Aïcha Salhi, Algiers, Algeria.

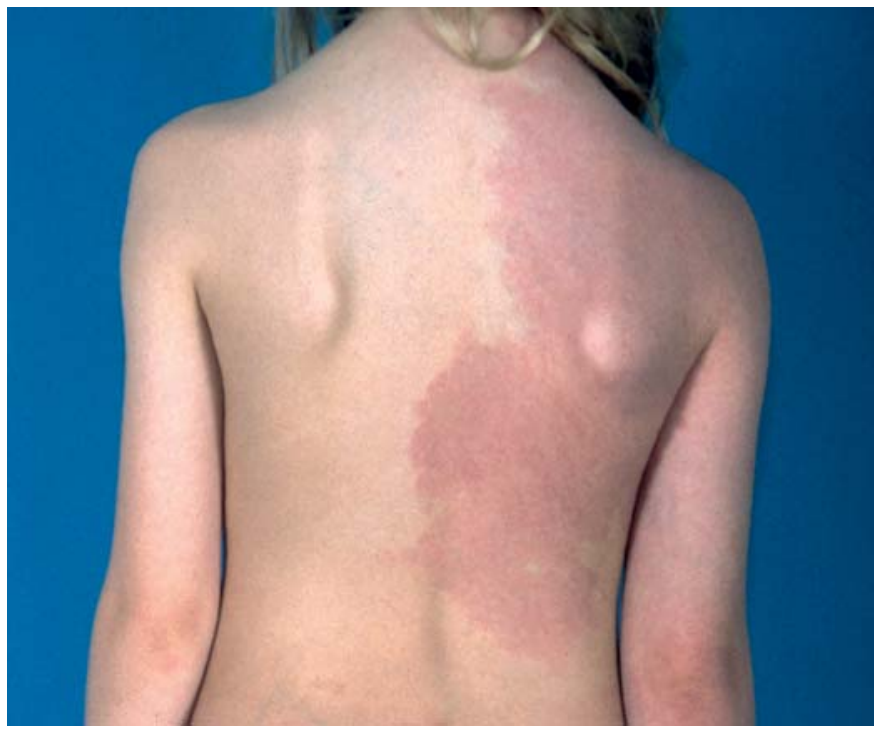

Fig. 3. Distinguishing criteria of nevus roseus are its pale pink color and flag-like arrangement.

row anemic halo $[5,7]$. Moreover, rhodoid nevi are the hallmark of an autosomal dominant trait, whereas both nevus flammeus and nevus roseus usually occur sporadically.

In practice, we should bear in mind that the clinical differences are sometimes not as clear-cut as documented in figures 1-3. For example, nevus flammeus may be rather light-red during infancy and thus be confused with the other two types of vascular nevi. So far, it is unclear whether these vascular lesions can be distinguished by histopathological criteria. In my view, this is rather unlikely. Notwithstanding, the proposed classification appears to be valid.

It should be noted, however, that the list of vascular nevi as presented in table 1 is not complete. Additional examples include cutis marmorata telangiectatica congenita, angiokeratoma circumscriptum and nevus anemicus $[8,12]$. Moreover, a peculiar median type of nevus flammeus is found in some patients with Van Lohuizen syndrome (cutis marmorata telangiectatica congenita syndrome) [13]. On the other hand, it should be borne in mind that the fashionable new term 'capillary malformation' $[1-3,6,7,14]$ includes several vascular lesions that do not represent nevi, such as the salmon patch and the telangiectatic lesions of Rendu-Osler disease [8].

In conclusion, we should no longer obey the presently prevailing linguistic prescriptivism that conflates dif- 
Table 1. Distingushing criteria of 3 types of vascular nevi

\begin{tabular}{|c|c|c|c|c|c|c|}
\hline $\begin{array}{l}\text { Type of } \\
\text { vascular } \\
\text { nevus }\end{array}$ & $\begin{array}{l}\text { Color of } \\
\text { nevus }\end{array}$ & $\begin{array}{l}\text { Archetypical } \\
\text { pattern of } \\
\text { nevus }\end{array}$ & $\begin{array}{l}\text { Evolution with } \\
\text { time }\end{array}$ & Syndromic associations & $\begin{array}{l}\text { Formal genetic } \\
\text { classification }\end{array}$ & $\begin{array}{l}\text { Molecular } \\
\text { basis }\end{array}$ \\
\hline $\begin{array}{l}\text { Nevus } \\
\text { roseus }\end{array}$ & pale pink & $\begin{array}{l}\text { segmental, flag- } \\
\text { like, sometimes } \\
\text { systematized }\end{array}$ & stable (?) & phacomatosis spilorosea & $\begin{array}{l}\text { usually sporadic; } \\
\text { paradominant } \\
\text { inheritance (?) }\end{array}$ & unknown \\
\hline
\end{tabular}

\footnotetext{
${ }^{1}$ Rarely, a type 2 segmental manifestation in the form of a segmental, flag-like pattern and arteriovenous fistulas of deep vessels is noted in this autosomal dominant trait.

${ }^{2}$ Includes some cases of spinal involvement (Cobb syndrome) and arteriovenous fistulas (Parkes Weber syndrome).
}

ferent vascular nevi by simply applying the umbrella term 'capillary malformation'. The proposed new name 'rhodoid nevus' will help clinicians to recognize 'CMAVM', a peculiar vascular phenotype that is inherited as an autosomal dominant trait and caused by RASA1 mutations [1].

\section{Disclosure Statement}

The author has no conflict of interest.

\section{References}

1 Eerola I, Boon LM, Mulliken JB, Burrows PE, Dompmartin A, Watanabe S, Vanwijck R, Vikkula M: Capillary malformation-arteriovenous malformation, a new clinical and genetic disorder caused by RASA1 mutations. Am J Hum Genet 2003;73:1240-1249.

2 Eerola I, Boon LM, Watanabe S, Grynberg H, Mulliken JB, Vikkula M: Locus for susceptibility for familial capillary malformation ('port-wine stain') maps to 5q. Eur J Hum Genet 2002;10:375-380.

3 Breugem CC, Alders M, Salieb-Beugelaar GB, Mannens MM, Van der Horst CM, Hennekam RC: A locus for hereditary capillary malformations mapped on chromosome 5q. Hum Genet 2002;110:343-347.

4 Online mendelian inheritance in man web site. http://www.ncbi.nlm.nih.gov/omim/ (accessed August 2, 2010).
5 Revencu N, Boon LM, Mulliken JB, Enjolras O, Cordisco MR, Burrows PE, Clapuyt P, Hammer F, Dubois J, Baselga E, Brancati F, Carder R, Quintal JM, Dallapiccola B, Fischer G, Frieden IJ, Garzon M, Harper J, Johnson-Patel J, Labrèze C, Martorell L, Paltiel HJ, Pohl A, Prendiville J, Quere I, Siegel DH, Valente EM, Van Hagen A, Van Hest L, Vaux KK, Vicente A, Weibel L, Chitayat D, Vikkula M: Parkes Weber syndrome, vein of Galen aneurysmal malformation, and other fast-flow vascular anomalies are caused by RASA1 mutations. Hum Mutat 2008;29:959965.

6 Hershkovitz D, Bercovich D, Sprecher E, Lapidot M: RASA1 mutations may cause hereditary capillary malformations without arteriovenous malformations. Br J Dermatol 2008;158:1035-1040.

7 Boon LM, Mulliken JB, Vikkula M: RASA1: variable phenotype with capillary and arteriovenous malformations. Curr Opin Genet Dev 2005;15:265-269.
8 Happle R: What is a capillary malformation? J Am Acad Dermatol 2008;59:1077-1079.

9 Happle R: Nevus roseus: a distinct vascular birthmark. Eur J Dermatol 2005;15:231-234.

10 Seckin D, Yucelten D, Aytug A, Demirkesen C: Phacomatosis pigmentovascularis type IIIb. Int J Dermatol 2007;46:960-963.

11 Jordaan HF, Happle R: Phacomatosis spilorosea associated with lymphoedema. Br J Dermatol 2008;159:489-491.

12 Danarti R, Happle R, König A: Paradominant inheritance may explain familial occurrence of cutis marmorata telangiectatica congenita. Dermatology 2001;203:208-211.

13 Happle R: Nichterbliche Genodermatosen. Hautarzt 1990;41(suppl 10):104-109.

14 Toriello HV, Mulliken JB: Accurately renaming macrocephaly-cutis marmorata telangiectatica congenita (M-CMTC) as macrocephaly-capillary malformation (M-CM). Am J Med Genet 2007;143A:3009. 